\title{
Gender Equality, Gender Inequality, and Gender Complementarity: Insights from Igbo Traditional Culture
}

\author{
Dorothy Oluwagbemi-Jacob, Chima Eni Uduma \\ University of Calabar
}

\begin{abstract}
The aim of this paper is to examine some theories of gender with a view to use them as bases for evaluating, assessing, and analyzing gender equality and inequality in Igbo traditional culture. In pursuance of this aim, particular attention will be paid to Igbo leadership practice. Were men and women equal in traditional Igbo culture? If they were, which theories of gender equality are thereby corroborated and which are refuted? Was the political landscape of the traditional Igbo a male terrain or was there a balance between men and women? What was the degree of participation of both men and women? The paper lays down certain criteria in order to determine equal or unequal or complementary status. These include access to resources, autonomy, and power. One or two lessons are drawn from the insights.
\end{abstract}

Keywords: gender, equality, culture, tradition, Igbo, complementarity

\section{Introduction}

Generalizations about gender, gender roles, and gender inequality are not uncommon. Pictures of masculinities and their contrasting femininities are painted in such a way that everything masculine is considered to be important, valued, and rewarded while the feminine aspect is assumed to be less important, less valued, and more often than not goes unrewarded. There is this binary structure that displays everything female as inferior, subordinate, oppressed, exploited, disadvantaged, put down and indeed parading subhuman qualities. This is the impression one gets reading many feminist authors, both western and African.

But one has to be cautious with such generalizations as evidence has shown that they are not true of women in all cultures and at all times. Traditional Igbo society of south east Nigeria provides one with a test case of a culture where the generalization of female inferiority does not hold.

The aim of this paper is to examine some theories of gender equality/inequality, relate them to gender practice in Igbo traditional culture with a view to show which theory of gender is corroborated or refuted therein. In pursuance of this aim, the paper lays down certain criteria. These include access to resources, leadership practice, autonomy, power, and decision making. This paper argues that gender relations in traditional Igbo African culture were complementary contrary to the unequal, superior, and inferior relationship generally believed to be the case between men and women. The Igbo form one of the largest ethnic groups in

Dorothy Oluwagbemi-Jacob, professsor, Department of Philosophy, University of Calabar, Nigeria; main research field: Social and Political Philosophy, Gender Issues, and African Philosophy. Email: doron32@yahoo.com.

Chima Eni Uduma, Department of Philosophy, University of Calabar, Nigera; main research field: Philosophy of Law. Email: eniuduma@yahoo.com. 
Nigeria with a population of over 30 million and have featured prominently in Nigerian politics both as individuals and as a group.

\section{Gender: A Conceptual Framework}

Conceptually, sex and gender are separate categories of the human condition. Sex is the attribute that characterizes one's biological condition of being a male or female. In respect of this definition, emphasis is placed on differences in chromosomes, anatomy, hormones, reproductive system, and other physiological components. Sex is a natural condition because a person is born with it. These attributes of being a male and female are universal and unchanging. For example, a man impregnates but only a woman can bear a child. The Athenian philosopher, Plato alludes to this distinction in his Republic (1974) when he says that the only difference between men and women is biological and one of physical function. He aptly captures his position thus, "the female bears and the male begets." Clearly, human beings without ambiguity can be placed in either category, which means that there is no middle course. One is either a male or a female. However, a third gender category has been identified in recent times with the attempt on the part of some to undergo major transgender surgery in order to change their sex from male to female and vice versa.

Gender connotes the differentiation between masculinity and femininity as constructed by society and inculcated through socialization and education. Unlike sex which is ascribed, gender is an achieved status because it is learned. According to Ivone Gebara, "gender is a socially learned concept, manifested, institutionalized, and transmitted from generation to generation” (2002, 1). This requires individuals to perform their roles, as men and women in conformity with what their culture expects of them. It affects not only the males and females but also the relationships, which they enter into. These conceptions about what are typically feminine or masculine characteristics: abilities and expectations, determine how men and women behave in various situations.

Gender forms an important basis for appreciating male/female relations in terms of sex roles in power sharing, decision making, division of labor, access to development benefits, and control over resources. Similarly, the assorted cultural, physical, institutional, social, and economic constraints, which men and women are confronted with, are products of the differential sex roles determined by gender.

Simone de Beauvoir's $(1953,295)$ view that one is not born woman but one becomes one aptly captures the picture. The ground for this is prepared through the socialization process, which starts from birth. Gender ideas are learned from families, friends, schools, the workplace, religious and cultural institutions, and the media and opinion leaders. The type casting of individuals, role assignment considered appropriate for both sexes, and the level of pressure forms part of the socialization process. Most societies share these roles and rights in such a way that they subjugate the female to the males. Clearly, they work to the disadvantage of the female.

In her work, "Psychology constructs the Female,” Naomi Weisstern (1971, 221-2) refutes biologically based theories that link sex differences to differences in sex hormones. She makes the point that little is known about innate sex role behavior and that there is no biologically natural female or male behavior. Thus, no immutable differences exist between men and women apart from differences in their genitals.

Bardwick and Douvan (1971, 233) unfold another perspective to gender affirming that the masculine qualities and achievements are esteemed by men and women. They make the point that a lot of women look down on themselves and evaluate their bodies, personality qualities, and roles as second rate. In their view, the 
culture values masculine productivity more than female productivity. They explain the situation thus: "the essence of the derogation lies in the evolution of the masculine as the yardstick against which everything is measured, since the sexes are different, women are defined as not-men and that means not good, inferior" (Bardwick and Douvan 1971, 234). The two authors call this "ambivalence" as it entails the simultaneous enjoyment of one's feminine identity, qualities, goals and achievements and the perception of them as less important, meaningful, or satisfying than those of men. Girls envy boys; boys do not envy girls (Bardwick and Douvan 1971, 234). Masculine endeavors are rewarded and those males who succeed-who acquire money, power and status, who acquire and produce things, achieve competition are celebrated (Bardwick and Douvan 1971, 234).

But the attributes that are associated with femininity such as the enhancement of and stabilization of relationships, as well as the female creation of life are not as highly esteemed by men and women alike (Bardwick and Douvan 1971, 234). In this regard, society values masculinity and rewards it when it is achieved. Since femininity does not weigh much in societal scale, it is not highly valued and rewarded when achieved. This point shall be related to Igbo traditional culture subsequently.

Contrary to the views expressed by the two authors, the traditional Igbo culture had a reward system that accommodated both female and male. Women and men who excelled in the sphere of their femininity and masculinity respectively were celebrated. For instance, in Edda traditional culture in Afikpo, if a woman gives birth to male children only, she is celebrated for enlarging the population of the community at the village level but if she gives birth to female children only, she is celebrated for enlarging the community at the family level. The culture also allowed successful women to take female, as well as male titles. Thus, Bardwick's and Douvan's position is not totally correct when applied to the Igbo traditional culture.

Gender discourse has given rise to a variety of theories. In what follows, efforts are made to highlight a number of them. The theories that are connected with the socialist perspective trace most societal ills, including gender inequality to the existing material inequality in society. They believe that once there is tremendous reduction of these material inequalities, the resulting social inequalities as well as their status hierarchies, will be almost eliminated. Following this, socialists assert that narrowing the gap in standards of living or property in a society will result in bridging the status differentials between men and women also.

Specifically, for Marxism, the genesis of all inequalities is the private ownership of the means of production by one class. This framework therefore contends that it is the historic role of the proletariat to eliminate all inequalities by expropriating the privately owned means of production consequent upon a revolutionary transformation of society and by the subsequent administration of the society for the benefit of all.

Consistent with the Marxian viewpoint, Engels makes the point that the cause of women's inferior status is class society and the forms of family organization, which it produces. He asserts that once class is abolished and the state withers away, the patriarchal family will also disappear. He attacks the capitalist mode of production for the plight of women. For Engels, capitalism separates the place of reproductive work (that is the family home), from that of productive work (that is the factory), and this has made women's participation in social production more difficult and limited. Capitalism, according to him, wants the women to keep producing the labor force without remuneration, while serving as cheap reserve army of labor. His program for full equality for women is their full participation in social production. What would be the implication of Engels' theory for the matriarchal family where ancestry is traced through the female members of the family? Can one 
still talk about the plight of women in such a society? While Engels emphasizes the economic aspect as being pivotal in the unequal relationship between men and women, in Igbo traditional society, it is culture that explains the relationship be it equal, unequal, or complementary.

In her theory, Lesser Blumberg (1984) claims that it is only the production of surplus resources and access to and control over these resources, that translates into power or valued success-for men and women alike. Blumberg's point plays out in Igbo traditional culture. That culture produced a category of highly resourceful, successful, and economically empowered women who could take male titles and wielded a lot of influence in their families and communities.

In buttressing Blumberg's position, Acholonu affirms that what determine social status in Africa, in all parts of Africa, are economic power and hardly gender. According to her,

A rich woman, an educated woman or enlightened woman who is outspoken, hardworking, and fearless can hardly expect to be looked down upon by any member of the society or of her own immediate family. On the contrary the family, community looks upon her and accords her recognition through traditional honors and titles. $(1995,44)$

Igbo traditional culture had a number of such women who by virtue of their success in commerce had accumulated so much capital in terms of material and non material goods that the society recognized them. Such women were granted the Ogbuefi title, which was one of the highest titles any Igbo man could take.

Writing about the Igbo cultural setup, Nkiru Nzegwu $(2004,563)$ makes the point that Igbo females do not have one gender identity given their multiple roles. Alluding particularly to umuada (lineage daughters), Nzegwu asserts that meaningful social ascription takes place at the level of the lineage and that umuada (lineage daughters) occupy a dominant position and are ever present forces in their natal families. They assume juridical and peacekeeping roles and regularly perform purification duties, as well as funeral rites for deceased members of the lineage (Nzegwu 2004, 563). Disagreeing with views that evaluate women as second rate or persons that play the second fiddle, Nzegwu maintains that in western Igboland, which is an achievement oriented society, individuals (both females and males) are expected to be industrious and to excel. Consequently, a social classification that subordinates women to men or vice versa cannot work (Nzegwu 2004, 564).

It is rather Victor Uchendu that throws more light on this point in his Igbo of Southeast Nigeria. According to him,

The African woman regarded as a chattel of her husband, who has made a bride wealth payment on her account, is not an Igbo woman, who enjoys a high socio-economic and legal status. She can leave her husband at will, abandon him if he becomes a thief, and summon him to a tribunal where she will get a fair hearing. She marries in her own right and manages her trading capital and her profits as she sees fit... She can have leasehold, take titles, and practice medicine. $(1965,87)$

This is an important point given views and theories that paint the picture of female inferiority and subordination as though they were true of all women at all times and in all places.

The practice of male daughters and female husbands is highlighted by Ifi Amadiume in her Male Daughters and Female Husbands. In this book, Amadiume talks about the flexibility of Igbo gender construction and makes the point that this is an indication or proof that gender is separate from sex. She affirms that there are occasions or situations when women can be male (Amadiume 1987, 15-16). Specifically, male roles were open to certain categories of women through such practices as "male daughters" and "female husbands.” These institutions placed women in a more favorable position for the acquisition of wealth and 
formal political power and authority. The Ekwe title for example, was an acknowledgement of female economic success and therefore, a reward for female industriousness (Amadiume1987, 123).

Like Amadiume and Nzegwu, Acholonu (1995, 39-40) mentions the practice of woman to woman marriage in Igboland where women husbands function as both "men" and "women." These are economically empowered women, rich, hardworking women who own property either bought or inherited. When they die, their property, which includes land, goes to the children of their "wives." Acholonu makes the point that these women take male or female titles or both, and upon death are given burials befitting titled male elders of the community. Once a woman (or wife) takes her own wife, she begins to shed her female roles. She is a man in all social, political, and domestic respects. Her husband being aware of this accords her full respect and deference.

\section{Gender Practice in Igbo Traditional Culture}

The traditional Igbo society practiced a flexible gender system in the midst of sexual polarization. Men and women were assessed or evaluated in accordance with the role expectations ascribed to them by the society. It had a conception of masculinity, which consisted in the men's duty to provide food for and protect their families (Amadiume 1987, 93). The female was groomed to be domestic, to be a good wife, be moral, to play motherly roles and be able to take care of her husband and help him financially, protect her children and support the household through farming, marketing, and trading. Right from her father's house, the woman was taught to be industrious for it would be profitable in her husband's house. Gloria Chuku has noted in this connection that,

Everything about her socialization as a girl was built around marriage and procreation. The girl was taught how to cook and provide domestic services to her husband. She was also trained in her mother's trade or sent away as an apprentice to learn other trades that would enable her take care of her children when the time comes. $(2013,272)$

Sexuality means different things for males and females and their sexual roles are defined by the culture. Control for sexuality was stricter for women than it was for the men. More emphasis was placed on the girl's virginity and the girls were expected to be highly moral and pure. The traditional Igbo culture was mindful of the biological differences between men and women. Moral strictures were heaped more on the woman because she is sexually more vulnerable than a man. A woman gets pregnant, a man does not. Thus, the socialization of girls stressed sexual restrain and preparation for their future roles as wives and mothers. Socialization of boys, on the other hand, stressed masculinity, equated with virility, violence, valor, and authority (Amadiume 1987, 94).

Until later childhood, there was no marked sexual difference between little boys and girls, both participated in what were deemed as female duties, which were mainly domestic. The child is expected to have general knowledge of things before he or she is made to specialize in areas assigned according to sex. The socialization process becomes differentiated later when the boys are taught qualities and attributes of masculinity, which include self assertion, adventurousness, independence, and self reliance. "Youth were encouraged to participate in wrestling, hunting, and masquerading” (Amadiume 1987, 94). They are groomed to take responsibility, to be in charge, to be involved in activities that will generate income, to be strong, not to show fear or emotion. Amadiume gives insight into what is expected of the young adult male in her study of Nnobi community: "He proved his masculinity when he participated in the war dances to display his treasures 
of war or from hunting wild beasts, boasting of his strength and courage, and wrestling with other brave warriors. He also proved his masculinity when he showed that he could fend for himself” $(1987,97)$.

Clearly, the scenario points to separate roles designed for males and females.

In specialized areas, exclusivity was not observed on grounds of value placed on sex, but on the biological and physiological make-up of the individuals. Performing different roles in any activity was complementary rather than discriminatory. For example, the man is trained to climb palm tree to harvest bunches of ripe palm fruits. These bunches fall freely and some of the ripe fruits scatter. The woman is therefore trained to gather and pick the scattered fruits and conveys them to the compound for processing. The woman is not trained for climbing, not because she is the weaker sex but to avoid exposing the private parts of her body to the public. It is therefore an abomination even while picking the palm fruits not to squat.

More often than not, the domestic front is generally taken to be the area of primary and natural assignment of women and activities concerned with preparation of food are taken to be menial in modern society. This is not the case in the Igbo traditional society. Domestic chores are meant for both sexes although with specialization and demarcated again on the basis of biological make-up. The males have the role of splitting firewood with axes, butchering and dissecting animals for cooking, pounding of yams or cassava etc. The females make the fire, do the cooking, and serve the meals etc. Even at the community level, when the entire village wants to clear the farm pathway, it is the men who clear the bush while the women prepare the meals they eat after the clearing. None of these tasks is considered more important or more prestigious than the other. The females would sweep the kitchen and the rooms of the family houses. The males sweep the vast compounds on which the houses are built. In all these chores, anything that would make the females expose the private parts of their bodies to outsiders is avoided and assigned to the males. For instance, climbing trees to pluck leaves for cooking, bending down to sweep the compound, split firewood, or other such functions, which are likely to reveal the private parts of their bodies, are considered out of bounds for the females in honor and maintenance of their decency.

The foregoing is an indication that the Igbo traditional gender relation is complementary in nature. A reading of Achebe's Things Fall Apart gives one this impression also. Specifically, highlighting the gender identity of Igbo deities and their human agents, Achebe makes the point that the female goddess, Ani, has a male priest Ezeani and the male oracle Agbala has a female priestess, Chielo. For instance, when Okonkwo violated the week of peace by beating one of his wives, his action offended the male priest of the earth goddess (Ani or Ala), who reprimanded him adding that such mistakes "can ruin the whole clan" (Achebe 1959, 26). Okonkwo was mandated to offer some sacrifices to propitiate the earth goddess.

\section{Gender Equality, Gender Inequality, and Gender Complementarity}

In this section of the paper, gender theories highlighted in this paper will be brought to bear on gender practice in order to show to what extent they support or corroborate claims about gender equality, gender inequality, or gender complementarity. In this regard, the paper employs access to resources, autonomy, and political participation.

\section{Ownership of an Access to Resources and Property Inheritance}

In many parts of Igbo traditional culture, women did not own land but they worked the land and managed most of its produce. In her study of Nnobi people, Amadiume $(1987,35)$ asserts that men owned two types of 
land: compound land for building houses, gardens, and farmland. The female exclusively worked the gardens with subsidiary crops and controlled their produce. Farmland, where major crops were grown, was worked by both men and women. Men were involved mostly during the initial planting and later harvesting but the daily job of tending was done by wives. The produce from this farm was shared by husband and wives with men controlling the distribution of yam. Notably, when yam no longer served as staple food due to poor output and poor storage, everyone turned to the women's crops: cassava, cocoyam, plantain, maize, and melons (Amadiume 1987, 38). One gets the impression in this regard that the two genders complemented each other in production even though ownership of the land is skewed in favor of men.

However, the sexual inequality entailed in the patrilineal principle of inheritance with regard to access to economic resources for daughters is quickly erased by women when they marry. This is usually achieved through their economic resourcefulness and enterprise because the girl child is socialized to learn a trade before marriage. Granted that property inheritance in the patrilineage excludes women, it is important to note however that this exclusion is not borne out of sexism. The logic behind it is that as women get married out, they cannot share property whether landed or otherwise with their brothers. In fact, this is why an average Igbo man is particular about having sons who will inherit his property when he is no more. Nonetheless, there is a category of women Amadiume (1987) has identified as "male daughters" who inherit property. These are those women who stay back in their family compounds without getting married in order to raise children for their families. But this practice is not widespread in Igbo land.

It is germane to mention at this point also that inheritance through patrilineage is not the only practice. Some parts of Igbo land (such as Afikpo, Ohafia, Abriba, Item) operate a maternal family system where the family line is traced to an ancestress or through a line of female members of the family. Everybody belongs to his or her mother's family and the system of inheritance of any farmland or most property is strictly matrilineal. Thus, if two persons born of the same father but different mothers are to cultivate their crops, their farms must be different except that their mothers are sisters from a maternal line. All property rights and inheritance are only possible through the mother's line except of course communal lands. For instance, if a man dies, all his property would be shared among members of his maternal family, including the clothes, seats, farm implements, fishing implements, hunting guns etc. The son shall inherit the empty barn while maternal family members shall inherit all the yams belonging to the deceased. This is because barn is built on communal land.

There is no dominion of the systems (patriarchy and matriarchy) over the other. The family is a large population of people scattered throughout the villages in small numbers.

Igbo traditional culture did not discriminate between males and females in terms of symbols of wealth. Title taking such as Ogbuefi was open to women, as well as men. Male roles were open to certain categories of women through such practices as "male daughters" and "female husbands." These institutions placed women in a more favorable position for the acquisition of wealth and formal political power and authority. The Ekwe title for example, was an acknowledgement of female economic success and therefore a reward for female industriousness (Amadiume 1987, 39; 123). It is clear from the foregoing that the Igbo gender system does not support Bardwick’s and Douvan's $(1971,234)$ theory that the society rewards masculine endeavors but fails to reward feminine ones.

Furthermore, there is another angle to gender practice in Igbo traditional culture when considered from the view point of Frederick Engels' theory. This consists in the fact that there is no separation between the world of work and the family. The family is the pivot of activity (productive and reproductive). The women are not 
consigned to inferior status by virtue of being visible in the family. Indeed, that visibility does not deny or rob them of social relevance. The dichotomy between the productive (factory work) and reproductive activity are features of modern industrial society. The Igbo traditional culture is rather integrative and the female flow in the two realms (family and society).

It is indeed Blumberg's (1984) theory that surplus resources and having access to such enhances women's position and power that supports or explains the autonomy of independence of Igbo successful women, as well as the taking of male titles. These powerful and assertive female figures who gain economic power through trade have been projected as great achievers. By any standard, there is no way one can see them as second class citizens. At the same time, the image of subordinate, passive, and vulnerable women is not what one sees analyzing the social circumstances of these women. Rather the picture one gets is that of strong, courageous, independent, and hardworking members of society whose roles were complementary (in the family and society), independent of men.

\section{Political Participation}

The political administration of the Igbo people of southeast Nigeria is republican in nature. The philosophy of collective efforts and decentralization characterize the system. There is room for all and sundry to participate fully in taking decisions. Michael Olisa $(1971,25)$ observes in this connection that the assembly of the whole town or village group is the highest platform for political decision and action. All adult males can attend and participate in the meetings of the town assembly. In such town assemblies, it is titled elders who preside over and deliberate over general discussions in a separate caucus and consultation called igba izu, and finally announce final decisions, which quite often win general vocal approval of the people.

Uchendu $(1965,40)$ distinguishes two layers of political structure. They include the village and the village group. At the village level, the accepted practice is direct democracy. At the village group level, a representative system is adopted and equality among the associating villages is maintained through the principle of "equal sharing of kola" and equal contribution of material resources needed for the survival of the group. Each village is autonomous and sovereign in most matters affecting it. The village is further segmented into a number of lineages and each lineage into major and minor lineages.

When one says that all adult males participate in village meetings, does it mean that there is no space for adult women? What picture does the scenario paint concerning gender equality or inequality as this pertains to political decision making? Views on this question vary. For instance, Theresa Agbasiere (2000) asserts that traditionally, women do not have active voice in purely political affairs... That is, the privilege of final says in any decision concerning matters of common interest... What women possess according to her is a consultative voice, which can exert significant political influence, especially in matters that concern women directly. In other words, women's voice in the political space is not completely drowned. It is consultative rather than active. But that of men is active. This in a way smacks of gender inequality.

Uchendu $(1995,58)$ rather makes the point that participation in the egalitarian traditional system of government is ensured through women's and men's associations, that is, a traditional dual sex political system, which is obtained in pre-colonial Igbo society. This facilitates representations and consultations on issues for communal decisions. In this way, women's participation in community decisions is assured. The women's activism as portrayed by the women's war of 1929 says a lot regarding the fact that women's voice is not silent. The outcome of that war which includes the abandonment of the warrant chief system and giving recognition to 
the traditional/indigenous rulers, the selection of whom is done by the community, including the representatives of women (Mba 1992, 82), is a pointer to the fact that the women who made such demands from the colonial authorities were neither timid nor passive. These were politically conscious women.

Highlighting this point further, Agara-Houessou-Adin (1998, IV) affirms that "Igbo women were at the forefront of political issues in Igbo land prior to the incursion of the Europeans." According to her, "the dual sex political system... allowed women to carry out their responsibility without infringing on the others' territory. It was highly developed form of democracy that existed, in that decisions were reached only after lengthy debates and persuasion either in the respective milieu or as a whole community.”

In some parts of Igbo land, for example, centralized Onitsha, Omu (the queen), and her councilors were concerned with the female section of the community (Okonjo 1976, 14). The market square and some other geographical spaces controlled by women were defined by the queen and her councilors as female zones to the exclusion of the men. Okonjo $(1976,13)$ affirms that the Queen's council was strongly represented in the king's court so that no trade legislation or transaction was made without their knowledge. The queen's power was enhanced by the power of Onitsha women. Commenting further on this political set up, Amadiume asserts that the queen's power was enhanced by the fact that she was in a position to mobilize the power of women. She further says that "the flexibility of gender in this political and cultural system thus favors the presence of women in the highest elite core of the society, whether in the status acquired or in the position of the kingship itself” (Amadiume 1987, 181). Henderson $(1972,376)$ observes that there is "tendency for prominent women to accumulate male symbols of prestige.” Indeed, Okonjo (1976, 310; 313) points out that in their ritual duties of performing market sacrifices and other town cleansing rituals, they were classed as males. It can be affirmed following the foregoing that the political landscape in Igbo traditional culture was not devoid of female presence.

Further, the role of Umuada in the various village governments in Igbo land cannot be overlooked. In this connection, Chuku $(2013,50)$ has identified Otu Umuada or Otu Umuokpu (society of daughters) of the lineage who might be married, unmarried, divorced, or widowed as a powerful force to reckon with especially in their natal lineages. According to her, this group acted as the police force against patrilineage wives, as well as ritual and purification specialists, and family psychotherapists. The Umuada also played important roles in creating unifying influences, settling intra-lineage disputes and quarrels between natal and marital villages. All this rules out the idea of subordinate, oppressed, suppressed, put down and inferior female.

\section{Lessons}

The gender situation of traditional Igbo was that of complementarity of roles where men, women, boys and girls, acted as members of a family or community to pool their resources together for the survival and benefit of all. That society absorbed women and encouraged female industriousness. It did not restrict the woman to the domestic sphere where she was expected to have no other role apart from being a good wife, mother and taking care of the family. Rather, the culture acknowledged and recognized the women achievers among them. Though differentiated on the basis of gender, this did not mean sex discrimination. Modern society can learn something from traditional Igbo gender practice that promoting gender flexibility and integration is more beneficial and eliminates the evils that inequality gives rise to, which includes the violations of women's rights (which are human rights). 
Another lesson to be learnt is that empowerment involves the way people take control and action in order to surmount barriers that confront them. Throughout history, a basic variable underlying the subjugation of women relates to the division of labor between sexes, which restricts women to domestic sphere with limited access to resources and decision making. The ground for this is prepared through the socialization process which starts from birth. But the scenario in Igbo traditional culture is different. "That society empowered the girl child. Though the girl child was prepared for marriage and the home, she was at the same time trained in her mother's trade or sent away to learn other trades that would enable her take care of herself and her home when the time comes" (Chuku 2013, 272). This explains the emergence of powerful and assertive female figures that gained economic power and could take both female and male titles. The principle has not changed. The call for women empowerment even in modern society is an affirmation that empowerment addresses the evils of subordination and oppression. It eradicates poverty, improves the status of women, and gives them access to control over resources such as land and money.

\section{Conclusion}

Following the results of the investigation of this paper, this paper maintains that theories that explain the universal subordination of women in terms of their material and domestic roles are not supported by the gender practice in Igbo traditional culture. Values are culturally determined and as such the importance that is attached to these roles will differ from culture to culture. These roles are highly valued in Igbo traditional culture but Engels for instance, finds them constraining and unrewarding. Consequently, the generalization pointing to the universal subordination of all women at all times and in all cultures appears somewhat hasty. What have been said concerning the Igbo women of traditional culture contradicts such generalization. Efforts should rather be made to critically examine the dynamics of Igbo traditional system, which made it possible for men and women to live and operate the way they did before modernity set in. Perhaps such can be adapted for purposeful and mutually enhancing gender relationship in our social, economic, and political systems.

\section{Works Cited}

Acholonu, Catherine. Motherism: The Afro Centric Alternative to Feminism. Owerri: Ate Publications, 1995.

Agbasiere, Joseph Theresa. Women in Igbo Life and Thought. New York: Routeledge, 2000.

Amadiume Ifi. Male Daughters, Female Husbands: Gender and Sex in an African Society. London: Zed Books Ltd., 1987.

Bardwick, Judith and Elizabeth Douvan. “Ambivalence: The Socialization of Women.” Ed. Vivian Gornick and Barbara Moran. Women in Sexist Society. New York: Basic Books Inc., 1977. 259-91.

Chuku, Gloria. “Nwanyibuife Flora Nwapa, Igbo Culture and Women’s Studies.” Igbo Intellectual Tradition: Creative Conflict in African Diaspora Thought. Ed. Gloria Chuku. New York: Palgrave Macmillan, 2013. 248-66.

De Beauvoir, Simone. The Second Sex. Trans. H. M. Parshley. Great Britain: Hazell Watson \& Viney Ltd., 1953.

Gebara, Ivone. Out of the Depths: Women's Experience or Evil and Salvation. Trans. Ann Ware. Mineapolis: Portress Press, 2002.

Mba, Nina. “Heroines of Women’s War.” Ed. Bolanle Awe. Nigerian Women in Historical Perspective. Lagos: Sankore Publishers, 1992. 82.

Nzegwu, Nkiru, “Feminism and Africa: Impact and Limits of the Metaphysics of Gender.” Ed. Kwasi Wiredu. A Companion of African Philosophy. Oxford: Blackwell Publishing Ltd., 2004. 560-94.

Plato. The Republic. Trans. Desmond Lee. 2nd ed. New York: Penguin, 1974.

Uchendu, Victor. The Igbo of Southeast Nigeria. New York: Holt Rinehart and Winston, 1965.

Uchendu, Patrick. Education and the Changing Economic Role of Nigerian Women. Enugu: Fourth Dimension Publishing, 1995.

Weisstein, Naomi. "Psychology, Constructs the Female.” Ed. Vivian Gornick and Barbara Moran. Women in Sexist Society. New York: Basic books Inc., 1977. 225-41. 